\title{
MOVIMENTOS DE INVASÃO DE SOLOS URBANOS E A JURIDICIZAÇÃO COLETIVA DOS CONFLITOS ${ }^{1}$
}

\section{Zelimar Soares Bidarra}

Resumo: Neste artigo, apresentamos algumas reflexões sobre o modo pelo qual, no contexto do processo de democratização do país, através da politização de suas lutas e práticas de juridicização coletiva dos conflitos, os movimentos de invasão de solos urbanos passaram a vivenciar as formas que se dão os critérios de legitimidade e de legalidade que especificam o direito de propriedade na legislação brasileira.

\section{Palavras-chave}

Lutas coletivas; Posse; Invasão e solo público

\begin{abstract}
In this article to apresentation some reflexions about how urban firm land invasion moviment to living legality and legitimation to be yours law propriety in brasilian legislation, transvesely yours faithing and practices to generall conflict.
\end{abstract}

\section{Keywords}

Generall faith; Possesions; Invasion and urban firm land

\footnotetext{
${ }^{1}$ Uma primeira versão deste artigo foi originalmente publicada na Revista Serviço Social e Sociedade, n. 64, SP, Cortez, 2000.
} 


\section{INTRODUÇÃO}

Esse texto trata das lutas coletivas pelo direito à posse do solo que foram empreendidas pelos movimentos de invasão de solos urbanos.

Os direitos são aqui tomados como práticas, discursos e valores que afetam o modo como desigualdades e diferenças são figuradas no cenário público, como interesses se expressam e os conflitos se realizam [...] os direitos não dizem respeito apenas às garantias inscritas na lei e instituições. $O$ que se está aqui propondo é pensar a questão dos direitos em um outro registro. [...] os direitos dizem respeito antes de mais nada ao modo como as relações sociais se estruturam. [...] os direitos constroem, portanto, vínculos propriamente civis entre individuos, grupos e classes [...] tudo isso [...] depende sobretudo de uma cultura pública democrática que se abra ao reconhecimento da legitimidade dos conflitos e da diversidade dos valores e interesses demandados como direitos (TELLES, 1994, p. 91-92).

Neste sentido, as reflexões desenvolvidas contêm um resgate do modo pelo qual, no contexto do processo de democratização do país, através da politização das suas lutas e das práticas de juridicização coletiva dos conflitos, os movimentos de invasão de solos urbanos abriram um campo fecundo para o enfrentamento dos critérios de legitimidade e de legalidade que especificam o direito de propriedade na legislação brasileira.

Os receios em relação às "ameaças" contidas nas ações coletivas de invasão estavam associados aos seguintes fatos: primeiro - as invasões coletivas de solos constituíam-se num fenômeno urbano relevante em virtude da amplitude e da adesão alcançadas por essa modalidade de luta pela conquista do direito à posse do solo urbano. E, segundo, estas ações passavam a demonstrar um potencial de ação organizativa e estrategicamente elaborada daqueles que, historicamente, foram excluídos ou destituídos das possibilidades de consumirem, pelas vias legais, os bens territoriais e imóveis produzidos pelas sofisticadas sociedades urbanas.

Deste modo, ainda que denominado como prática espúria e de violação do bem patrimonial de outrem, o fenômeno das invasões coletivas gerou movimentos organizados, cujos avanços das lutas possibilitaram as inflexões nos estreitos limites formais de proteção à propriedade 
privada imputados pelos mecanismos jurídico-políticos.

Para isto, foi preciso conseguir que a noção de posse prevalecesse como parâmetro das interpretações jurídicas, quando da apreciação das questões postas em conflito. A insistência nesta perspectiva tinha um motivo concreto, isto é, era preciso manter a inteligibilidade sobre as invasões vinculada às disputas pelo direito de posse, porque deste modo abria-se um espaço fecundo para os avanços pretendidos por estes movimentos. Pois, as disputas quando relativas ao direito de posse criam condições mais favoráveis para a introdução de outros argumentos que melhor polemizam o estatuto da legalidade e da legitimidade que impõe, a custos sociais elevados e indiscriminados, a proteção e a guarda da propriedade privada.

Sendo assim, os protagonistas desses movimentos insistiam na defesa e na legitimidade da invasão. Para eles a invasão era legal e legítima porque fora o último recurso utilizado para defenderem os seus direitos de ter acesso à moradia. Segundo Moura (1994, p. 16): “...alegam os invasores que é preciso ir além da lei e considerar o valor social da moradia". A defesa do recurso à invasão como opção derradeira e legítima era acompanhada de apelos que se fundamentavam nos argumentos da necessidade e da ausência de alternativas que lhes garantissem o direito de ter onde e como morar.

As discussões acerca da legitimidade e da legalidade destas formas de apropriação ganharam destaque quando as lutas pelo direito à posse do solo, via invasão, provocaram inúmeras interpelações judiciais das partes envolvidas nos conflitos. Ou seja, a questão da ausência de moradia nas áreas urbanas para os segmentos populares ganhou notoriedade quando da luta pelo reconhecimento do direito à posse do solo originou-se um relevante movimento de juridicização coletiva dos conflitos ${ }^{[}$.

[...] a industrialização acelerada
das últimas décadas, ao
produzir uma nova e mais
complexa composição de
classes, também gerou conflitos
inéditos, para os quais as leis e
seus respectivos procedimentos
judiciais não forneciam mais
respostas satisfatórias e
eficazes. O que as invasões de
terra, as ocupações de edifícios
públicos e privados e os
acampamentos de protesto
passaram a reverter, ao longo
dos últimos anos da década de
oitenta, é, neste sentido, uma
infinidade de relações
desprezadas pelas instituições

${ }^{2}$ A juridicização coletiva dos conflitos consistiu numa estratégia de remeter para o interior do poder judiciário as disputas sobre a posse e/ou reconhecimento da legitimidade do direito reclamado. 
políticas e jurídicas. Preparado para resolver questões interindividuais, mas nunca as coletivas, o direito oficial não alcança os setores mais desfavorecidos - e a marginalização jurídica a que foram condenados esses setores nada mais é do que subproduto de sua marginalização social e econômica (FARIA, 1992, p. 21-22).

A agudização das desigualdades e o recrudescimento das condições materiais fizeram os movimentos sociais partirem em busca de formas de resolutividade para o que era percebido como legítimo direito. Concorreu para isto a politização e "as mobilizações organizadas canalizaram-se para o plano legal-institucional [...], ou seja, passou a ocorrer um processo de juridicização da sociedade organizada" (GOHN, 1991, p. 11).

A juridicização foi a estratégia utilizada para reivindicar às carências cotidianas. A partir de então o Judiciário passou a ter uma posição de destaque frente aos conflitos e às disputas que envolviam os movimentos de invasão. O direcionamento das lutas para esses espaços produziu resultados inesperados que, a princípio, causaram estranheza para os que acreditavam na inviolabilidade da titularidade jurídica da propriedade. Para Moura (1994, p. 22) a novidade observada nas atuações do Judiciário deveu-se ao seguinte fato: “...esta prática, ao reconhecer $\mathrm{o}$ interesse social que configura o direito à moradia, contribuiu para a inserção de conceitos sociais na argumentação jurídica." Donde se depreende que para o caso das lutas dos movimentos de invasão as possibilidades de mudanças na natureza das decisões judiciais dependem essencialmente da força dos argumentos utilizados e da sua capacidade de flexionar a predominante postura legalista que estrutura o exercício da prática jurídica.

Nessa ocasião, os movimentos de invasão para reivindicarem o direito à posse do solo e a justiça "provocaram", 0 Judiciário pela via da pressão coletiva e organizada. A prática de juridicização coletiva extrapolava os mecanismos formais de regulação jurídica. "A natureza contraditória do processo - ocupação à revelia em terreno de outrem em face da necessidade primária de moradia - exige a

\footnotetext{
3 O termo "provocar" tem um significado específico para o Judiciário, isto é: o Judiciário só pode intermediar um conflito quando é exigida a sua interferência por qualquer uma das partes envolvidas no conflito. Diferentemente dos outros poderes estatais o Judiciário "só atua mediante provocação” (FARIA,1994b).
} 
mobilização do aparelho estatal responsável, em última instância, pela manutenção da ordem social" (SOUZA, 1991, p. 72).

Através da juridicização coletiva dos conflitos a “[...] longa história da técnica jurídico-processual de individualizar os conflitos começa a ser questionada por movimentos reivindicando soluções coletivas [...] destrói-se um pouco a crença do direito-mito, mas fica aberta a crença no direito-ação" (Lopes, 1990, p. 201). O recurso coletivo ao Judiciário marcou o protagonismo dos movimentos de invasão de solos urbanos, de suas lutas pela posse do solo e pelo direito à moradia. Sendo a juridicização uma característica intrínseca dessas lutas e que a singulariza frente as demais lutas dos movimentos sociais.

\section{A JURIDICIZAÇÃO COLETIVA DOS CONFLITOS}

$\mathrm{Na}$ década de oitenta, as tensões e as disputas políticas na sociedade brasileira favoreceram a explosão de litigiosidade $\mathrm{a}^{\frac{1}{1}}$, e a juridicização coletiva dos conflitos

4 Explosão da litigiosidade foi a terminologia, inicialmente, utilizada pelos profissionais que atuam no âmbito do Direito para caracterizar a forma como os movimentos organizados da sociedade civil implementada pelos movimentos de invasão de solos urbanos. A crescente politização e participação coletiva da sociedade civil nas demandas por direitos e justiça contribuíram para retirar o Judiciário da situação de isolamento e alheamento com relação aos conflitos coletivos de natureza político-social. No entanto, o resgate era problemático porque o Judiciário sempre se instrumentalizou numa concepção normativa de legitimidade e de legalidade cuja aplicabilidade supõe o campo dos conflitos interindividuais. Sendo assim, para intervir em conflitos coletivos, que focalizavam direitos sociais, foi preciso que o Judiciário admitisse a necessidade de recriar as referências argumentativas e interpretativas na produção das suas decisões. Isto o fez experimentar sérios dilemas em virtude da sua orientação dogmática - busca a preservação da imparcialidade, da neutralidade e da objetividade $\mathrm{e}^{\mathrm{G}}$ frente ao objeto ou fato da adjudicação

reivindicavam os direitos sociais.

5 “A objetividade é uma noção inseparável da idéia do exercício de domínio[...]. Por seu intermédio, uma realidade é convertida em objeto de conhecimento. Algo é conhecido objetivamente quando é possível dominá-lo teoricamente e, portanto, dominá-lo praticamente" (Chaui in Faria (org.), 1988, p. 41).

$6 \mathrm{Na}$ esfera do exercício do Direito o ato de 
neutralidade e a imparcialidade do Judiciário não passam de uma ficção cultivada por uma cultura jurídica isolada e idealista" (FARIA, 1994a, p. 161).

Assim, a juridicização dos conflitos provocou a politização das decisões judiciais. Gradativamente, o Judiciário foi pressionado para abandonar o seu caráter de a-politicismo e a-historicismo. Sob pena de ter descaracterizada a sua autoridade institucional, o Judiciário, foi compelido a introduzir na sua retórica o sentido histórico dos processos sociais implementados pela sociedade brasileira na década de 80 . Isto porque a organização sócio-estatal no capitalismo expressa a totalidade das relações capitalistas e cabe ao Estado criar os meios de gerenciamento das relações sociais.

O Estado estruturou o poder judiciário para garantir as relações de produção e de troca com a finalidade de reproduzir as relações mercantilizadas do capitalismo. Esta operação se realiza através da “‘juridicização” do ser humano”, que se expressa através da figura jurídica do

adjudicar significa "conceder a posse de (qualquer coisa), por decisão ou setença da autoridade judicial" (Ferreira,1980, p. 44). sujeito de direito 7 , caracterizado como ser individual, isolado, singular e destituído de historicidade social (coletiva ou de classe). No plano jurídico o sujeito de direito é tomado como "ser único" que representa o conflito de natureza interindividual, “...o modelo liberal de direito e de Estado, pressupõe a abstração de indivíduos concretos na decantada figura normativa do 'Sujeito de Direito'” (FARIA, 1994a, p. 10).

O subjetivismo do Direito mistifica as contradições e as desigualdades sociais na personificada "pessoa" jurídica. A sociedade burguesa esconde a essência das suas relações sociais na gênese da mercadoria e fetichiza a dimensão histórico-social do ser na pulverizada e subvertida "pessoa" jurídica, de tal forma que ela se torna o objeto do Direito e sobre si impõem-se as "ferramentas" normativas dos "operadores", 8 que, freqüentemente, adotam um comportamento de preservação da estrutura dogmática existente; assim

\footnotetext{
7 A denominação sujeito de direito - compreende uma construção conceitual do Direito que impõe aos "operadores" uma concepção subjetivista do ser, formalizada pela situação ideal-abstrata da "igualdade de todos perante a lei".

8 "Operadores" do Direito é uma terminologia que tem sido utilizada, por uma vertente crítica do Direito, para denominar os juízes, promotores e advogados cujas atuações se fundamentam na
} 
sendo, não incorporam a inteligibilidade conflitiva do social nas suas intervenções, com isso negam o potencial explosivo da sociedade e usam reiteradamente princípios estáticos nas arenas de juridicização. A concepção estática dos princípios de legalidade, de legitimidade e de justiça se fundamenta no positivismo jurídico, visando a reprodução da peculiar historicidade burguesa.

Ao esvaziar as lutas sociais de seus conteúdos políticos, este modelo, remete à atuação do Judiciário para uma situação atemporal e destituída de sentido histórico. Ao negar a relação história/ conflito, desloca os conteúdos das ações conflitivas para o espaço de uma racionalidade, meramente, ideal-abstrata, que nem sempre é suficiente para conter os processos sociais como, por exemplo, aqueles vivenciados pela sociedade brasileira nos anos 80 , nos quais as lutas pelo acesso ao solo são partes constitutivas. A intensificação destas lutas produziu um novo cenário conflitivo. $\mathrm{O}$ que favoreceu o questionamento da legitimidade e da legalidade jurídico-políticas que organizavam as relações sociais no país. Caso contrário, "como formalizar homens, historicamente situados numa situação de profunda desigualdade real, num único 'Sujeito de Direito?' (FARIA, 1994a, p. 10).

As lutas pela posse do solo deram outra dimensão política às interlocuções entre o poder estatal e os movimentos de invasão. O cerne constitutivo dessas lutas é “delicado" e complexo porque está atrelado à questão da propriedade privada e “...a questão fundiária urbana, apesar de aberta e insistentemente questionada, continua uma espécie de tabu" (Aragão, 1994, p. 65). Quando se trata de interferir no âmbito da propriedade privada desloca-se a interlocução para o âmbito do Direito, ou melhor, para os espaços legitimados de proteção das "sagradas aquisições privadas dos cidadãos”. Porque a preservação “dos direitos individuais" é de responsabilidade de um certo modelo jurídico de corte liberal.

Para driblar a inspiração individualista desse modelo, os movimentos de invasão enfatizaram a dimensão coletiva de suas lutas e demandas por direitos. Nessa modalidade de correlação de forças, o princípio do individualismo não devia se sobrepor às tentativas de negociação que 
envolviam as demandas porque "...para os invasores o princípio justificativo é o da necessidade; nos demais casos prevaleceria o princípio da acumulação" (MOURA, 1994, p. 24).

A conquista de sentenças judiciais favoráveis à permanência ou posse do solo dependeu da força dos argumentos utilizados na sustentação do processo de juridicização. Donde se conclui que a lógica inovadora do argumento foi decisiva para tornar o conjunto das desigualdades sociais numa fonte identificação e de justificação da transgressão praticada. O Judiciário foi ocupado por aqueles que retratam e que configuram o drama da pobreza $^{\text {a }}$ e dos pobres ${ }^{10}$ da sociedade

\footnotetext{
${ }^{9}$ A noção de pobreza não se restringe aos aspectos econômico-materiais porque eles não revelam todos os seus determinantes. Segundo ARENDT (1991, p. 74): “[...] A pobreza força o homem livre a agir como escravo. [...] Donde se concluiu que a pobreza está para além das ausências materiais, visto que os efeitos por ela produzidos ampliam as condições da submissão e da subalternidade em geral, que se justifica no tautológico jogo do 'pobre cidadão livre', porém escravo da peça que a vida lhe pregou."

10 “A categoria POBRE tem uma definição ética e histórica que implica considerar os resultados da produção, não só a acumulação do capital, mas também a acumulação da pobreza que dela resulta. A realidade social passa a ser considerada não a partir da igualdade jurídica que sustenta as ficções básicas sobre os direitos, mas a partir da desigualdade econômica e social que desmarcara e denuncia a falta de direitos" (Martins apud Poleto, 1993, p. 29-30).
}

brasileira. Para eles as leis e o Direito sempre tiveram o caráter de "um filme de ficção", que transmite imagens distantes, artificiais e descompassadas de uma realidade que não lhes é peculiar.

As irrupções da conflituosidade no interregno do Judiciário projetaram os sinais de um novo tempo, que surgia das brechas e das cissões com as fórmulas de gerenciamento das relações políticas no país. "[...] o judiciário passa a ser uma instância regularizadora das relações sociais, esperança entre aqueles que buscam e lutam pela diminuição das desigualdades e injustiças sociais" (GOHN, 1991, p. 15).

A versatilidade das lutas dos movimentos de invasão buscava interferir na interpretação dos institutos jurídicos que estipulam a prevalência do direito de propriedade sobre qualquer outro direito. As reivindicações dos protagonistas das invasões pautaram-se nas denúncias das situações de desigualdade, fragilidade e necessidade a que estavam expostos. A administração jurídica destes conflitos requereu a crítica sobre os princípios que definem a relação entre posse e propriedade no Direito. Era visível que não se 
conseguiria solucionar estes conflitos com o uso imediato das prerrogativas jurídicoformalizadas. Segundo Falcão(1984, p. 82), geralmente, $\mathrm{o}$ “[...] equacionamento destes conflitos foi obtido por uma atuação combinada entre normas e valores do direito estatal oficial e normas e valores 'outros'. Ora, estas normas e valores 'outros' apontam para uma concepção de direito em geral [...] distinta da que se estruturou e se vivifica no direito estatal dominante."

Para reverter o quadro das desigualdades sociais era preciso construir novas formas de inteligibilidade do social. Isto requeria a reinvenção dos argumentos de legalidade e de legitimidade que fundam as relações político-jurídicas. No bojo dessas lutas a relação com o poder judiciário era um dado novo e relevante.

Nesta perspectiva, estava embutida a idéia de que o Judiciário não podia ser apenas um "operador" do Direito, mas o seu "recriador", se quando provocado inovadoramente, aceitasse o desafio de dialogar com a lei num campo mais amplo do que o formalizado. A promessa da realização da justiça permanece condicionada à deliberação do Judiciário, porém não deve se restringir a uma mera aplicabilidade da legislação codificada. Muitas vezes, a realização da justiça, depende de fatores que escapam à rigidez, ao imobilismo e ao formalismo cristalizados na dogmática do positivismo jurídico.

Para efetivar a justiça reclamada pelos movimentos de invasão, o poder judiciário não pôde ficar indiferente às tensões instaladas e nem insistir na tese da exterioridade do Direito. A realização desta justiça exigia a produção de "novos" pressupostos de legalidade e legitimidade que flexibilizassem a lógica do dogmatismo jurídico para abri-la para outros sujeitos e outros direitos. Este "novo" modo de produção jurídica deve considerar o Direito como um fenômeno sócio-histórico.

Ao se reivindicar direitos também se reivindica legalidade e legitimidade. Mas, se de antemão estes princípios expressam compromissos ideológicos, políticos e econômicos com determinada classe social, não resta outra alternativa para "os sem direitos" senão tentar ampliar tais compromissos. 
A juridicização coletiva foi o meio utilizado pelos movimentos de invasão para ampliar as fronteiras que protegem os direitos dos interessados na manutenção de tais compromissos, visto que: "O direito é a expressão mais alta da tradução ideológica do poder. Ele estabelece os princípios, delimita as condutas, defende as atitudes e 'ofende' as outras por meio da sanção" (Aguiar, 1984, p. 80). O Direito é um instrumento de regularização dos interesses e a sua ação não comporta a imparcialidade porque o seu resultado concreto corresponde à satisfação unilateral. “Assim, o direito é ideológico, é interessado, é parcial e é uma ordem emanada do poder para controlar os destinatários segundo os interesses e a ideologia dos grupos que legislam [...], a essência do direito é ser parcial" (Aguiar, 1993, p. 115).

A prática jurídica que apreende o Direito pela via restrita da existência formal de cidadãos livres e iguais apenas reproduz as "crenças" de que a "perfectibilidade" do Direito se resume ao atendimento do objeto reclamado por “[...] indivíduos autônomos e atomizados, como pessoas privadas e membros (cidadãos) da comunidade política" (Faria, 1994b, p. 21). Esta prática jurídica precisa da relação formal, distante e neutra das categorias jurídicas frente aos "conturbados rompimentos" provocados pelos "sujeitos de direitos". A suposta neutralidade do Direito embute a idéia de que só assim é possível distribuir a justiça da forma devida.

Ainda assim, a processualidade social pode criar uma juridicidade instituinte. Aproveitando-se das lacunas e interstícios existentes no Direito, as práticas sociais que reagem à estreiteza e ao reducionismo do positivismo jurídico podem pressioná-lo com o intuito de expandir o seu âmbito de conformação. As práticas sociais instituíntes que objetivam outras formas de produção da legitimidade devem pôr sob o crivo de uma crítica minuciosa a idéia de que o Direito necessita do abismo entre o espaço público e a vida privada. A idéia de justiça como um processo dá um outro enfoque para as práticas que procuram romper com o caráter legitimador da ordem das coisas instituídas. Mais do que rejeitar tais fórmulas, estas práticas aceitam o desafio de enfrentá-las e reconstruí-las sobre novos fundamentos. 
Nos conflitos emergentes se inscrevia o questionamento $d a$ legalidade instituída (certamente, uma legalidade estreita) pois rompiam as fronteiras do permitido $e$ impunham o reconhecimento de novos critérios de legitimidade e justiça [...]. Por isso mesmo, suas reivindicações apareciam como exigência de direitos e de um critério de justiça que punha em questão as decisões do Estado no campo social... (TELLES, 1984, p. 108).

Inseridos nestas práticas os movimentos de invasão protagonizaram um processo de enfrentamento contra as instituídas fórmulas de legalidade e de legitimidade que especificam o Direito e a justiça. E, o debate sobre a questão dos assentamentos no espaço urbano passou a ter centralidade no elenco das preocupações governamentais depois que inúmeras decisões (ou até mesmo não-decisões)

${ }^{11}$ Segundo Falcão isto se deu porque o Judiciário foi posto no centro de um tipo de conflituosidade não habitual à sua prática institucional. O Judiciário ficou tensionado pelo seguinte dilema: "Não se trata de interpretar a lei de acordo com seus fins sociais. É mais do que isto. Trata-se simplesmente de não aplicar a lei em nome dos fins sociais. Ou seja, o Judiciário hoje é o local onde se buscam tanto decisões toleráveis, quanto não-decisões. $\mathrm{O}$ que importa é constatar que o Judiciário, seja pela flexibilidade interpretativa, seja pela impunidade no não-decidir, pode hoje - legal, ilegal ou paralelamente - tanto aplicar uma concepção de direito de propriedade de como a do Art. 524, quanto qualquer outra. [...] $\mathrm{Na}$ medida em que a não-decisão judicial é cada dia mais provável, o uso judiciais reconheceram como legítimo o direito à posse solo.

Sob o signo das lutas por direitos, os movimentos de invasão reivindicaram ao poder público a efetivação dos direitos sociais. A "descoberta" dos direitos não foi um fenômeno exclusivo desses movimentos, mas consequiência de determinações sócio-políticas - as dimensões da "questão social" - colocadas para a sociedade brasileira durante a democratização.

O que significa que o aparelho judicial jamais pode ser analisado de modo isolado, fora do contexto das estruturas sociais que produzem as contraditórias relações sociais. Tais contradições gestam as condições para as alterações no mundo jurídico porque: (1) são formas constitutivas de manifestações das desigualdades sociais que resultam do conjunto das atividades materiais que produzem um modelo de Estado e de sociedade e (2) neste modelo estão concebidos os formatos institucionais que representam e que dão sentido ao Estado; sendo assim, as instituições jamais

do direito positivo estatal como a 'ameaça de violência possível' cada dia coage menos os invasores" (FALCÃO, 1984, p. 94). 
conseguem se expressar fora do modelo e nem são autônomas em relação a ele.

O Judiciário experimentou as inflexões decorrentes do processo de democratização porque o Direito, embora tenha a pretensão de formalizar a harmonia, tem intrínseco em sua lógica a idéia do conflito; as lutas pelos direitos são feitas nas histórias dos conflitos (AGUIAR, 1993).

Desde que grupos sociais tradicionalmente alijados do acesso à Justiça descobriram os caminhos dos tribunais, orientando-se por expectativas dificilmente moldáveis à rotinas judiciais, utilizando de modo inventivo os recursos processuais e explorando todas as possibilidades hermenêuticas propiciadas por normas de "textura aberta", como [...] as normas que se caracterizam por conceitos indeterminados, o Judiciário se viu obrigado a dar respostas para demandas para as quais não tem nem experiência acumulada nem jurisprudência firmada (FARIA, 1994b, p. 52-53).

As lutas dos movimentos de invasão pela defesa dos direitos sociais e da justiça pautaram-se em argumentos que favoreciam o confronto com o caráter individualista que preside a lógica da cultura jurídica brasileira, na qual “[...] o individualismo e a propriedade são o pilar de sustentação da cultura jurídica" (Lopes, 1994b, p. 82). A apropriação das noções de direitos imprimiu uma mudança qualitativa nas formas de interlocução política desenvolvidas pelos movimentos de invasão. O eixo das lutas foi articulado sobre a "linguagem de direitos" dava outra visibilidade à questão das disputas do solo urbano. Tal "linguagem" é a chave para entender os conflitos e as problemáticas explicitadas pelos movimentos. Para reivindicar a igualdade e os "direitos ao solo e a moradia", estes movimentos inverteram a compreensão das categorias que determinam o exercício do Direito e da Justiça.

Os invasores, como nebulosos "sujeitos de direito”, relacionaram suas problemáticas com as questões de direitos, forçaram a ampliação e o deslocamento das formulações que definem a legalidade e a legitimidade do direito de propriedade e demandaram um Direito reelaborado. Para esses movimentos, falar em direito significava pôr em primeiro plano a questão da posse da terra, e não a "velha"

12 O termo "linguagem de direitos" tem sido utilizado para caracterizar as situações em que os movimentos organizados da sociedade civil partiram para os enfrentamentos com o Estado fundamentando as suas reivindicações nas noções de direitos sociais. 
questão da propriedade já garantida pelo Direito.

Demandar novos estatutos de legitimidade e de legalidade para a questão da posse da terra exigia a confrontação direta e inesgotável com a retórica formalista do Direito. A "nova” legalidade e legitimidade implicava na flexibilização e ampliação dos critérios jurídicos face às configurações da realidade social; isto representava a inclusão dos invasores no mundo dos direitos e da justiça. A defesa do direito à posse do solo era a defesa da possibilidade manter-se vivo dentro das complexas situações que acometem a realidade urbana.

A "linguagem de direitos" foi um poderoso instrumento de barganha política do direito à igualdade. Principalmente, no âmbito do Judiciário que é o espaço reconhecido para dirimir as dúvidas quanto a quem tem direito à essa igualdade e por que a tem. Além do que a politização dos conflitos e os freqüentes enfrentamentos entre movimentos de invasão e poder judiciário culminaram na rejeição à idéia de justiça como valor abstrato, que não absorvia e nem contemplava as reais demandas dos movimentos. Para eles, a idéia de justiça reportava-se a um valor concreto, um bem material realizável, a posse do solo. Sendo assim, a realização da justiça dependia de uma solução que confirmasse a prevalência do direito social ante uma regra positivada, visto que esta última apenas simboliza o imaginário social codificado em leis.

Através da juridicização dos conflitos, os protagonistas das invasões pretendiam provar que se encontravam numa situação de total iniquiidade econômica e que as prerrogativas econômicas, as regras legais e oficiais do mercado, não podiam ser utilizadas para classificar como ilegais as ações de invasão. Deste modo, forçavam o deslocamento da natureza econômica que determina o significado da propriedade do solo. Com isso objetivavam restituir à propriedade um significado mais amplo - o valor social.

A desatualização dos instrumentos jurídicos diante da complexidade da vida social, principalmente nos espaços caracterizados pela intensificação dos processos urbano-industriais, dificulta $\mathrm{o}$ ocultamento das suas lacunas " [...] o direito deixou, nas entrelinhas, uma possibilidade para o réu clandestino, um injusto possuidor, obter um lugar para a sua moradia" (Moura, 1994, p. 11). Isto 
proporcionou o acirramento das "complicadas" tentativas de inversões dos estatutos coagulados do mundo jurídico. As ambigüidades dos conceitos que regularizam o mundo da produção jurídica serviram de suporte para as práticas de juridicização coletiva dos conflitos que pressionam o dogmatismo jurídico.

Ao se basearem nas situações de necessidade e de privação para demonstrarem publicamente os limites das suas experiências cotidianas, os movimentos de invasão, caracterizavam o ato de invasão como o recurso derradeiro diante da ausência de outras perspectivas. Para esses movimentos era fundamental requalificar o sentido das ações, a negatividade do termo invasão induz a análise para o campo da criminalidade, e aos criminosos não cabe reivindicar direitos. O importante era poder enfatizar a precariedade das condições de vida e a dimensão social da problemática.

A atuação dos movimentos de invasão colocou o poder judiciário diante de situações inéditas, pois trouxeram para as instâncias jurídicas elementos "estranhos" aos parâmetros que informam esse poder. O "estranho" estava relacionado ao uso de justificativas inquestionáveis e legítimas que exprimiam as condições de perversidade e de destituição geradas pelo o processo de desenvolvimento social "[...] o direito oficial passa a ser revigorado pelo conteúdo social da argumentação jurídica” (Moura, 1994, p. 02).

Os conflitos criaram situações inusitadas porque as reivindicações pelo direito à posse da solo forçavam o recuo dos obstáculos legalistas que protegem o direito de propriedade. A intensificação das lutas no interior do Judiciário, diversas vezes, fizeram-no enveredar por caminhos não tão consistentes onde os seus princípios analíticos e decisórios mostravam-se inadequados para controlar os conflitos que extrapolavam a previsibilidade convencionada no Direito.

\footnotetext{
Caracterizar as invasões sob a ótica do direito oficial é importante para compreender em que aspectos os conflitos de propriedade, por um lado, tornaram maleáveis os rígidos contornos da lei e, por outro, resgataram o uso deste direito em favor das comunidades marginalizadas. [...] é fundamental diferençar as invasões ocorridas em terras privadas daquelas ocorridas em terras públicas, tendo em vista que a argumentação
} 
jurídica pode enveredar por caminhos distintos a depender da natureza da propriedade envolvida no conflito (MOURA, 1994, p. 08-09).

Os argumentos utilizados procuravam reforçar o teor social do objeto em questionamento porque esta tem sido a forma de reivindicar a legitimidade dos precários direitos. $\mathrm{O}$ acesso ao direito à moradia precisou vencer as resistências da prática jurídica em reconhecer a prevalência dos direitos sociais, mesmo quando o objeto do conflito comprova uma legítima situação de risco para aqueles que o reivindicam.

\section{[...] os direitos sociais surgiram juridicamente como prerrogativas dos segmentos mais desfavoráveis - sob a forma normativa de obrigações do Executivo [...]. A característica básica dos direitos sociais está no fato de que [...] foram formulados dirigindo-se menos aos indivíduos tomados isoladamente como cidadãos livres e anônimos e mais na perspectiva dos grupos, comunidades, corporações e classes a que pertencem [...] cuja proteção exige apenas que o Estado jamais permita sua violação (FARIA in FARIA(org.), 1994b, p. 105).}

A efetivação dos direitos sociais depende da intervenção estatal porém, na sociedade brasileira a violação dos direitos sociais é histórica e tem sido uma constante na organização sócio-estatal. O descaso e a falta de prioridade para com os direitos sociais pode ser explicado da seguinte forma:

[...] os direitos sociais não configuram um direito de igualdade [...]; são isto sim, um direito das preferências e das desigualdades, ou seja, um direito discriminatório com propósitos compensatórios; um direito descontínuo, pragmático $\mathrm{e}$ por vezes até mesmo contraditório, quase sempre dependente da sorte de determinados casos concretos [...] os direitos sociais são politicamente editados com o objetivo de socializar riscos, neutralizar perdas e atenuar diferenças, mediante tratamento diversificados por parte das múltiplas instâncias do setor público (FARIA, 1994b, p. 105106).

$\mathrm{Na}$ sociedade brasileira os direitos sociais são concebidos como "não-direitos". A falta de interesse político em regulamentar os direitos sociais como legítimos direitos de cidadania, não é nova em nossa história. Traduz as características da dominação e da sujeição que estão na raíz da cultura política brasileira - para a qual o indivíduo desprovido das condições materiais nunca é um cidadão e sim um "cliente" das dádivas e das migalhas concedidas à mercê dos interesses políticos dominantes. Esta 
cultura política se reproduz investindo na ampliação das fronteiras da desigualdade e na desqualificação brutal dos párias da sociedade. Evidentemente, “[...] um cidadão que se vê obrigado a aceitar as razões da força, e não a força das razões de seu contendor, é um não-cidadão" (LOPES in FARIA (org.), 1994b, p. 74).

A reprodução de um contingente expressivo de "não-cidadãos" tem sido funcional porque facilita a conservação das relações de submissão. Deste modo, as instituições orientadas pelos parâmetros do formalismo político-jurídico se apresentam como que desencumbidas de responsabilidades e indiferentes ao grave quadro de dificuldades que dele resulta. Os beneficiários do formalismo investem pesadamente contra a legitimação dos direitos sociais porque enquanto tais direitos permanecerem no campo do tratamento residual continuam tendo à sua disposição uma massa significativa de “não-cidadãos" ávidos por "garantirem” a cidadania em "troca" de algum "favor" prestado.

Essas garantias, porém, continuam sendo essencialmente "liberdades burguesas". São excelentes para quem pode alcançá-las.
Difícil, porém, é explicar sua importância a quem da cidadania só tem o título de eleitor, porque mal sabe ler, não ganha para alimentar a família, não tem carteira assinada e só interessa à Justiça quando se transforma em réu (KUNTZ, 1994b, p. 155).

Dentro das lutas contra as imposições coercitivas e sancionadoras das leis vocação original do Judiciário - as lutas dos movimentos de invasão ganharam destaque porque investiram contra as formas de subjugação que costumam confiná-las num quadro classificatório que vai desde o "levante dos insubordinados", até os “contra a lei”. Estes códigos são oportunos para desqualificar e banalizar as formas de protestos e de resistências dos "nãocidadãos".

$\mathrm{Na}$ realidade, a sobrevivência das lutas destes movimentos dependeu da capacidade de articular propostas alternativas que não recuassem diante do peso desses rótulos. Exigiu-se perspicácia para reverter os argumentos que impregnados pelas regras de moralidade e arraigados pelas "razões da força" usurpava o acesso aos direitos de cidadania. Diversificando as investidas esses movimentos usavam as "suas desgraças" 
para convencer aos "operadores" do Direito que as suas reivindicações não eram infundadas e nem contrárias à ordem legal. Os movimentos alertavam para o fato de que as suas lutas sinalizavam para formas diferenciadas de conceber o ordenamento legal e, por isso, as ações de invasão não eram entendidas como atitudes transgressoras. Mas, as invasões foram alternativas para resistir aos imperativos das "razões da força" que lhes impossibilitava ter acesso à direitos.

“[...] nós não somos fora da lei, porque a lei diz que todo o cidadão brasileiro tem que ter direito a um salário que cubra as necessidades básicas de moradia, transporte, alimentação, etc. Se esse direito não é garantido pro povo, a partir daí o povo tem que buscar seus direitos [...] Daí eu vejo que nós tamos morando numa vila legalmente construída, porque nós já pagamos muito caro pelo valor desse terreno com o nosso trabalho [...]" (PANIZZI, 1990, p. 203 - depoimento de um invasor).

$\mathrm{O}$ ato da invasão era associado à idéia da inevitabilidade, da falta de alternativa, da força da circunstância, da "desesperança ante a injustiça social" ou da "fracassada história de sujeito". As modificações no formato e no conteúdo das alegações visavam interferir no modo como os “operadores" do Direito costumavam administrar a justiça. Os invasores não se consideravam como indivíduos ilegais, mas como produtos das misérias da sociedade . "Eu não me considero fora da lei pelo seguinte: porque nós não somos as únicas pessoas que invadiram terra prá nós ter um direito de ter um canto pra poder viver [...] se existe tanta gente assim como nós, é porque têm alguma coisa errada [...] não somos nós os errados [...]" (PANIZZI, 1990, p. 202 - depoimento).

Os invasores costumam demonstrar que se tivessem tido outras alternativas jamais enfrentariam este tipo de situação. O argumento da inevitabilidade tem o propósito de distanciar o ato da invasão de qualquer motivação política. “[...] eu não tenho condições de pagar aluguel e não posso sair daqui [...] se eu sou invasor, essa situação me incomoda, eu gostaria de pagar as prestações dessa casa e ter os papéis dela" (PANIZZI, 1990, p. 202 depoimento).

Os argumentos utilizados pelos invasores traduzem o porquê da "legitimidade" e da "legalidade" das suas ações. Afinal o que impele à invasão são os desejos e o direito 
de poder viver uma vida melhor. Além do que este direito não é individual, mas da coletividade em questão. Ressaltando à dimensão coletiva deste direito não aceitam as idéias de "perversão", "esbulho", "vício", "indevida", “incorretas" ou "irregulares" que constam na classificação legal-formal sobre este tipo de posse.

Certos de que "possuem direito" e de que "desejam apenas justiça", os movimentos de invasão buscam o Judiciário para legitimarem o direito que a sociedade lhes negara. Para promover este tipo de justiça, os "operadores" devem recorrer a uma jurisprudência ${ }^{13}$ reparadora que confirme a prevalência dos direitos sociais sobre o direito individual (ou do proprietário privado). Para conseguirem esta "inversão" (ou subversão) das prioridades, estes movimentos aprendem a importância “[...] da necessidade da utilização não-burguesa da legalidade burguesa, especialmente no âmbito judicial" (FARIA, 1994 ${ }^{\mathrm{a}}$, p. 12).

\footnotetext{
${ }^{13}$ A jurisprudência significa "a ciência do Direito e das leis. Conjunto de soluções dadas às questões de direitos pelos tribunais superiores. Interpretação reiterada que os tribunais dão as leis, nos casos concretos submetidos a seu julgamento" (Nuñez,1986-1987). Logo, a jurisprudência compreende a ação interventiva daqueles que trabalham o Direito, segundo seus códigos, regras e instrumentos.
}

Os movimentos de invasão pressionaram o Judiciário para praticar a justiça, porém o que estava por detrás desta noção de justiça, não era a conceituação legal-formal - “dar o seu de cada um” -, mas uma motivação para recuperar o que lhes era "devido".

Neste deslocamento do enfoque formal para o enfoque real estava posta uma exigência "cara" para os "operadores" do Direito, qual seja: para efetivar esta justiça precisavam se despojar das "razões da força" e avançar os limites da racionalidade jurídica do Direito.

[...] veja-se, a título de ilustração, a seguinte sentença da $3^{\mathrm{a}}$ Câmara do $1^{\mathrm{o}}$ Tribunal de Alçada Civil de São Paulo, num processo de reintegração de posse: "Levando a realidade de São Paulo à presunção de que favelados são pessoas comuns, pois as favelas cada vez mais se estabilizam nesta cidade, e que aqueles não são necessariamente vadios ou marginais, mas apenas pobres, não há como se afastar a aplicação do princípio constitucional da função social da propriedade, mesmo porque não há, nos autos, prova alguma de que os possuidores sejam marginais do ponto de vista jurídicopenal (FARIA, 1994b, p. 106). 
Os estudos ${ }^{14}$ que têm tentado reinterpretar o Direito a partir de referências da sociologia jurídica registram modificações qualitativas nas práticas jurídicas quando elas se preocupam em refletir sobre a dimensão e o efeito social do Direito.

Considerando a tendência à inovação nas interpretações em que prevaleceram as referências sociológicas, os estudiosos do Direito observaram que: as lutas populares que provocaram a juridicização coletiva dos conflitos levaram os "operadores" do Direito a exercitarem uma prática mais dialética na produção da justiça. Pois a normatização do Direito, nas suas lacunas, comporta a tensa dinâmica das contradições sociais (AGUIAR, 1993).

Não parece absurdo o fato de as lutas dos movimentos de invasão demonstrarem que a temida "desordem" ou "turbação" contra a propriedade pode ser recomposta dentro dos interstícios do Direito. Estes insterstícios possibilitaram a realização da justiça reclamada pelos movimentos invasão, porém sem que as estruturas do Direito sofressem reveses.

14 A abordagem da prática jurídica enfocada neste trabalho se baseou nos estudos dos profissionais do Direito que tentam criticar e rever os fundamentos norteadores das suas práticas.
A força do argumento do direito à moradia gestou as condições para a tensão da lógica jurídica acerca da relação entre o legal e o legítimo. A flexibilização do Judiciário frente ao "novo" suscitado pelos movimentos de invasão mostrou que este poder contribui com os processos de redefinição do social, quando os seus "operadores" perseguem a finalidade última do Direito que é a realização da justiça.

\section{REFERÊNCIAS BIBLIOGRÁFICAS}

AGUIAR, Roberto A. $\mathrm{R}$ de. Direito, poder e opressão. 2 ed. SP. Alfa-Omega, 1984.

O que é justiça: uma abordagem dialética. 3 ed. SP. Alfa-Omega, 1993.

ARAGÃO, José W.M. de. Movimento popular de luta pela terra: Salvador, 197988. Cadernos do CEAS, Salvador - BA, n.149, 1994.

ARENDT, Hannah. A condição humana. 5 ed. Rio de Janeiro. Forense, 1991.

BIDARRA, Zelimar S. Os Movimentos de Invasão de Solos Urbanos e a democratização brasileira: a "linguagem de direitos" e as demandas por justiça. RJ, 1996. Dissertação (Mestrado em Ciências Sociais) Uiversidade Federal do Rio de Janeiro, RJ. 
DAGNINO, Evelina (Org.). Anos 90: política e sociedade no Brasil. São Paulo. Brasiliense, 1994.

FALCÃO, Joaquim de Arruda (Org.). Conflito de direito de propriedade: invasões urbanas. Rio de Janeiro. Forense, 1984.

FARIA, José Eduardo (Org.). A crise do direito numa sociedade em mudança. Brasília : Editora da UnB, 1988.

. Direito e justiça: a função social do Judiciário. São Paulo : Ática, 1994a.

Direitos humanos, direitos sociais e justiça. SP. Malheiros. 1994b.

FARIA, José Eduardo. Justiça e conflito: os juízes em face dos novos movimentos sociais. 2 ed. São Paulo: Revista dos Tribunais, 1992.

FERREIRA, Aurélio Buarque de $\mathrm{H}$. Médio dicionário Aurélio. Rio de Janeiro : Nova Fronteira, 1980.

GOHN, Maria da Glória. Luta pela moradia popular em São Paulo movimentos de moradia (1975/85). Ciências Sociais Hoje. São Paulo, ANPOCS/Vértice, 1988.

- Movimentos sociais e luta pela moradia. São Paulo. Loyola, 1991.

LOPES, José Reinaldo L. Direito e práxis social. Revista de Informação Legislativa (separata). Brasília. Ano 27, n. 105, jan./mar. 1990.

MOURA, Alexandrina S. de. Espaço urbano, direito e conflitos coletivos no Brasil: do argumento jurídico ao argumento social. ENCONTRO ANUAL DA
ANPOCS, 17, 1994, Caxambu. [Anais...]. Caxambu : [s.n.], 1994. (Mimeogr.).

NUÑEZ, Antônio C. O poder judiciário no Brasil: tendências e leituras. Boletim Informativo e Bibliográfico (BIB). 2. ed. Englobando do n. 11 ao 14. São Paulo, ANPOCS/Cortez, 1986-1987.

PANIZZI, Wrana M. Da legalidade para a ilegalidade: a formação de microterritórios urbanos. In: OLIVEIRA, N. et al. (Org.). O Rio Grande do Sul urbano. Porto Alegre - RS. FEE, 1990

POLETTO, Ivo. Cadernos do CEAS. Salvador - BA. N. 148, dez., 1993.

SOUZA, Angela Maria Gordilho. Invasões, intervenções e perspectivas - o caso da cidade de Salvador. Cadernos do CEAS. Salvador - BA. N. 136, nov./dez., 1991.

TELLES, Vera da S. A experiência do autoritarismo e práticas instituintes: os movimentos sociais em São Paulo nos anos 70. São Paulo. 1984. Dissertação (Mestrado em Ciências Sociais) Universidade de São Paulo, São Paulo.

Pobreza e cidadania: precariedade e condições de vida. In: MATINS, Heloísa H. T. de; RAMALHO, José Ricardo. Terceirização - diversidade e negociação no mundo do trabalho. São Paulo : Hucitec/CEDI/NETS, 1994. 
Zelimar Soares Bidarra

Professora do Curso de Serviço Social da UNIOESTE/PR. Doutoranda em Educação pela Faculdade de Educação - UNICAMP e membro do Grupo de Estudo e pesquisa em

Movimentos Sociais, Cidadania e Demandas Educativas GEMDEC-FE/UNICAMP

Artigo aceito em: 13/12/2002 